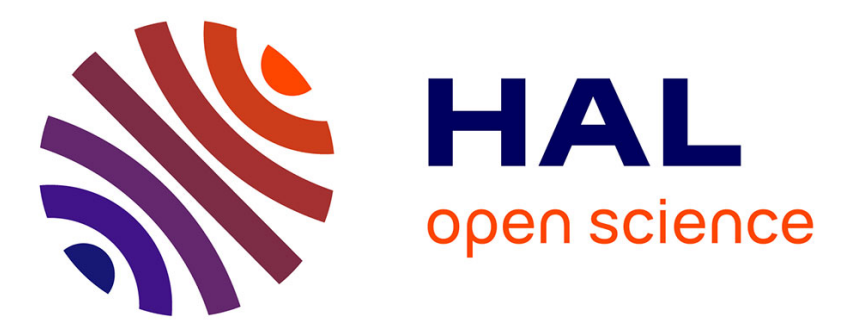

\title{
Education 4.0 Reference Framework for the Design of Teaching-Learning Systems: Two Case Studies Involving Collaborative Networks and Open Innovation
}

\author{
Jhonattan Miranda, María-Soledad Ramírez-Montoya, Arturo Molina
}

\section{- To cite this version:}

Jhonattan Miranda, María-Soledad Ramírez-Montoya, Arturo Molina. Education 4.0 Reference Framework for the Design of Teaching-Learning Systems: Two Case Studies Involving Collaborative Networks and Open Innovation. 22nd Working Conference on Virtual Enterprises (PRO-VE 2021), Nov 2021, Saint-Etienne, France. pp.692-701, 10.1007/978-3-030-85969-5_65 . emse-03350017

\section{HAL Id: emse-03350017 https://hal-emse.ccsd.cnrs.fr/emse-03350017}

Submitted on 25 Nov 2021

HAL is a multi-disciplinary open access archive for the deposit and dissemination of scientific research documents, whether they are published or not. The documents may come from teaching and research institutions in France or abroad, or from public or private research centers.
L'archive ouverte pluridisciplinaire HAL, est destinée au dépôt et à la diffusion de documents scientifiques de niveau recherche, publiés ou non, émanant des établissements d'enseignement et de recherche français ou étrangers, des laboratoires publics ou privés. 
Miranda J., Ramírez-Montoya M.S., Molina A. (2021) Education 4.0 Reference Framework for the Design of Teaching-Learning Systems: Two Case Studies Involving Collaborative Networks and Open Innovation. In: Camarinha-Matos L.M., Boucher X., Afsarmanesh H. (eds) Smart and Sustainable Collaborative Networks 4.0. PRO-VE 2021. IFIP Advances in Information and Communication Technology, vol 629. Springer, Cham. https://doi.org/10.1007/978-3-030-85969-5_65

\title{
Education 4.0 Reference Framework for the Design of Teaching-Learning Systems: Two Case Studies Involving Collaborative Networks and Open Innovation
}

\author{
Jhonattan Miranda, Maria Soledad Ramírez-Montoya, Arturo Molina \\ School of Engineering and Sciences, Tecnologico de Monterrey, Mexico City, Mexico \\ \{jhonattan.miranda, solramirez, armolina\}@tec.mx
}

\begin{abstract}
Collaborative networks and open innovation have high potential as codrivers of value creation for many production and service sectors such as education. In higher education, it is increasingly frequent to observe universities implementing teaching-learning systems with collaborative processes supported by 4.0 technologies. Moreover, various pedagogical procedures, research activities, and co-development projects have complemented these types of collaborative processes, which today are considered desirable to be carried out within Education 4.0. In this paper, the authors propose a reference framework for designing new teaching-learning systems using the concept and vision of Education 4.0. The proposed reference framework considers key enablers of Education 4.0 and three dimensions to analyse and evaluate decisions made: (i) Technological, (ii) Pedagogical, and (iii) Organisational. Finally, two case studies involving collaborative networks and open innovation illustrate how the proposed reference framework is used.
\end{abstract}

Keywords: Collaborative Network - Open Innovation - Higher Education · Educational Innovation · Education 4.0

\section{Introduction}

Nowadays, technological advancement due to the capabilities and capacities of 4.0 technologies (connectivity, digitalisation, virtualisation, smartification, datafication, among others) has allowed practically all the productive and service sectors to improve their processes, leverage resources, and even grow and expand to other regions [1]. As a result, 4.0 technologies have played a very relevant role to promote and improve collaboration processes, internally in organisations and externally, in the exponential formation of Collaborative Networks (CNs) [2]. In higher education, implementing strategies based on collaborative processes has been increasingly frequent since these allow improving teaching-learning processes that promote the participation of academicians and students in collaborative environments. Moreover, these strategies put them in real scenarios that allow them to work on joint projects to propose solutions to current challenges and problems. Currently, models such as the triple helix (involving the participation of academia, industry, and government) and the quadruple 
helix that adds the participation of society (e.g., users, consumers, citizens, workers) have been implemented to support these dynamics [3].

In higher education, collaboration is essential to provide adequate active learning environments, activities, and resources for the training and development of the core competencies necessary for the profile of the 21 st-century student. In this context, it is necessary to implement new teaching-learning systems that stimulate collaboration and complement their activities using 4.0 technologies, innovative learning processes, and adequate infrastructure. In education, these pedagogical procedures, collaborative activities, and 4.0 technologies are known today as Education 4.0.

Currently, various design approaches focused on innovative educational systems within the Education 4.0 context consider not only the instructional and didactic aspects but also the psychological, motivational, and engagement ones [4]. In addition, approaches for the instructional design of modules meeting the requirements of Education 4.0 exist [5]. Other design approaches take up the specific design of products and tools for learning and infrastructure design for suitable teaching-learning environments. These approaches separately address the product, processes, and infrastructure development in education and are not conceived in an integrated approach. This work proposes an integrated reference framework employing the Education 4.0 vision and concept in the design of teaching-learning systems.

The rest of this paper is structured as follows: Section 2 presents the concept of Education 4.0 in higher education and its four key enablers. Section 3 shows the current relevance of collaborative networks applying open innovation strategies. Section 4 presents the proposed reference framework. Section 5 presents two case studies. Finally, the conclusions and future work are presented in Section 6.

\section{Education 4.0 in Higher Education}

Education 4.0 is a relatively new concept recently approached by different authors and implemented in various contexts in higher education. This concept arises from the relationship between 4.0 technologies particular to the Fourth Industrial Revolution and the Education sector. Therefore, the use of current and emerging technologies for pedagogical purposes is known today as Education 4.0. However, other authors have been more specific with this concept, referring to Education 4.0 exclusively as developing necessary competencies in engineering education for Industry 4.0 [6]. Recently, the World Economic Forum developed a framework for Education 4.0 based on critical shifts in learning content, development of critical skills and competencies, and experiences that redefine quality learning in the new economy [7]. Recently, the combination of heutagogy, peeragogy, and cybergogy approaches has emerged under Education 4.0 [8].

This work follows the concept of Education 4.0 as described in the following reference:

"Education 4.0 is the period in which the education sector takes advantage of emerging ICTs to improve pedagogical processes that are complemented by new learning methods and innovative didactic and management tools, as well as the smart 
and sustainable infrastructure used during current teaching-learning processes for the training and development of key competencies in today's students" [8].

Therefore, identifying the key enablers to achieve the Education 4.0 vision is necessary to guide educators during the teaching-learning processes. Four categories of key enablers are used during the design and implementation of today's teachinglearning systems: (i) Identifying crucial soft and hard competencies necessary to be developed by today's students; (ii) Incorporating new learning methods in educational programs with different modalities for information transfer and teaching-learning methods; (iii) Implementing current and emerging ICTs considering technology-based solutions and current tools and platforms, and (iv) Employing innovative infrastructure (architecture, facilities, services, and platforms) to improve learning processes at two levels, namely, the classroom/home level and the institutional level. These enablers then allow new teaching-learning systems to emerge under the vision of Education 4.0.

\section{Collaborative Networks Applying Open Innovation Strategies}

Organisations have increasingly adopted collaborative processes from different sectors as part of their continuous improvement, growth, and expansion activities. Nowadays, thanks to technological advancement and the use of 4.0 technologies, the implementation of these activities have grown exponentially. They have led to new tools and best practices. They have also facilitated creating links so key entities and actors can collaborate from different productive-service sectors at local, regional, and international levels [9]. In addition, the global health emergency of 2020 - 2021 has dramatically increased the implementation of collaborative platforms and accelerated the digital transformation of many organisations and academic institutions [10]. This has opened new opportunities for distance collaboration on synchronous and asynchronous activities. These current dynamics make collaborative-based processes accessible and flexible between different actors [11].

Consequently, encouraged organisations from all sectors (academia, government, industry, and citizens) have generated collaborative and cooperative practices. It is becoming more common to find these actors networked and interdependent. Collaborative networks and open innovation (OI) have served as frameworks to shape these practices. These concepts have shown a high potential to be co-drivers of value creation and sharing resources, knowledge, complementary skills and capacities, and even share responsibilities and risks getting as a consequence not only the creation of disruptive processes, products, and services but also to make the most of resources, to shorten development processes, and to increase social impacts [12].

In this context, CNs are defined as "a network that consists of various entities that are largely autonomous, geographically distributed, and heterogeneous in their operating environment, culture, social capital and goals. They have come together to collaborate to achieve better common or compatible goals; their interactions can be supported by computer networks" [13]. 
Since CNs induce OI strategies, OI has been used to define the networked nature of innovation processes [9]. Thus, OI strategies combine internal and external ideas, resources and technologies, and create synergies among various multidisciplinary actors [14]. Hence, implementing these strategies plays a primary role in networks ability to facilitate innovation and spur the openness of innovative processes.

Therefore, today, collaborative networks applying open innovation strategies are excellent drivers for collaboration in Education 4.0. Hence, through multidisciplinary collaborative activities, academicians and students can participate in different scenarios internally in their institutions and externally in projects with actors participating in the triple-helix and quadruple-helix models.

Today, in higher education, OI strategies are widely used in different universities because these dynamics allow the structured participation of different actors for education and research, development, technology transfer, and entrepreneurship. Therefore, higher education institutions leverage these dynamics to develop curricular strategies and strategies that link companies and academicians through collaborative projects. These activities have been considered effective in achieving the vision of Education 4.0 because they induce active learning processes and the implementation of current ICTs.

\section{Education 4.0 Reference Framework for designing teaching- learning systems}

We propose a reference framework for designing new teaching-learning systems based on the concept and vision of Education 4.0. The proposed reference framework relies on the theory of enterprise modelling, using instantiation processes that facilitate enterprise integration $[15,16]$. This reference framework aims to guide designers during the design and development of new didactic products, teaching-learning processes, and educational infrastructure through the generation of generic, partial, and particular models. Then, modelling is done through the instantiation of a generic model to partial and particular models. The definition of these models allows designers to systematically perform activities and apply techniques and tools when creating any teaching-learning system. Thus, the generation of these models allows designers to take advantage of previous knowledge and experiences that result in the shortening of the design, development, and implementation processes.

This framework has four stages related to the development life cycle. Hence, didactic products, teaching-learning processes, and educational infrastructure can be created through the following four stages of development: (i) Ideation. At this stage, ideas are generated and evaluated, and then they can be created and implemented in new products, programs or facilities. Also, at this stage, activities focus on understanding the educational institution's needs, the social contexts, and the student's profile to migrate these needs into requirements. (ii) Basic development: At this stage, designers provide the concepts underlying the proposed solutions. Therefore, all the functions or attributes that the product/process/infrastructure must include are defined. In addition, in this stage, the identified learning goals must be aligned to the proposed concept. (iii) Advanced development: The product/process/infrastructure is detailed designed at this stage. At this point, the design process can be complemented using any design methodology for teaching-learning systems to determine the learning content, 
dynamics, and instructions to be implemented. At this point, designers determine the capacities and capabilities and consider the four key enablers of Education 4.0 as a reference. Then, designers identify: (a) the key competencies to be promoted, (b) the learning methods to be implemented, (c) the ICTs to be applied, and (d) the required infrastructure to carry out the teaching-learning process. Once the proposed solution is obtained, it has to be evaluated and validated; then, the i-scale tool evaluates the innovation, learning outcomes, growth potential, institutional alignment, and financial viability, among others [17]. (iv) Launching. At this stage, all the implications to the proposed solution execution process must carry out. Some of the generic activities to be performed are tests of implementation and evaluation, design of experiments, and pilot tests. Finally, the learning assessment must be applied. The evaluation of the students is very relevant at this point since the information obtained serves to discover any weak aspect during the teaching-learning process that can be improved. Therefore, evaluation mechanisms must be applied and aligned with the measurement of learning goals. Figure 1 presents the proposed reference framework for the design of teachinglearning systems in Education 4.0. Then, different activities have been defined to carry out these stages. See Fig. 1.

These activities can be selected according to the following models:

Generic model. This model contains generic activities that can be used to design any teaching-learning system in a general way. Consequently, designers can reference generic models and then configure them to obtain partial or particular models.

Partial model. During the definition of this model, the designers take advantage of previous knowledge and then apply it within a specific field or discipline. Consequently, the partial activities to be performed and the partial resources to be used must be defined.

Particular model. Designers must define the specific topic and themes to be addressed. Also, specific requirements must be considered to define the specific learning methods, tools, ICTs, and infrastructure to be implemented. Therefore, the previously mentioned generic activities receive a deep level of specification. The resulting teaching-learning systems will be highly particularised to a specific social context, field, discipline, and topic.

Also, our proposed reference framework provides a toolbox that allows the designer to reference the type of resources that can be applied. The toolbox is organised per the main enablers considered in the concept and vision of Education 4.0: (i) The main soft and hard competencies to develop; (ii) the learning methods to be considered in new teaching-learning dynamics; (iii) the implementation of current and emerging ICTs for technology-based solutions using existing tools and platforms, and (iv) the use of an innovative infrastructure to improve pedagogical procedures and managerial processes at two levels, the classroom/home level and the institutional level.

Finally, once the product, process or infrastructure has been obtained, it will be necessary to analyse and evaluate it per the following views: (i) Technological, which seeks to validate the use of technologies characteristic of Industry 4.0; (ii) Pedagogical, which seeks to validate the implemented activities that promote the training and development of desirable competencies in Education 4.0; the activities must follow an active teaching-learning methodology of current learning models, and (iii) Organisational, which seeks to verify that the proposed learning dynamics have an 
organisational structure that is important to identify key participants (internal and external) within teaching-learning processes. In addition, this view verifies that the proposed activities promote collaboration and cooperation initiatives.

Figure 2 presents an example of how each cell of the reference framework includes different activities (analysis, synthesis, and evaluation) to be performed and how these activities are supported by the key enablers of Education 4.0 and analysed and evaluated according to the proposed views (technological, pedagogical, and organisational). See Fig. 2.

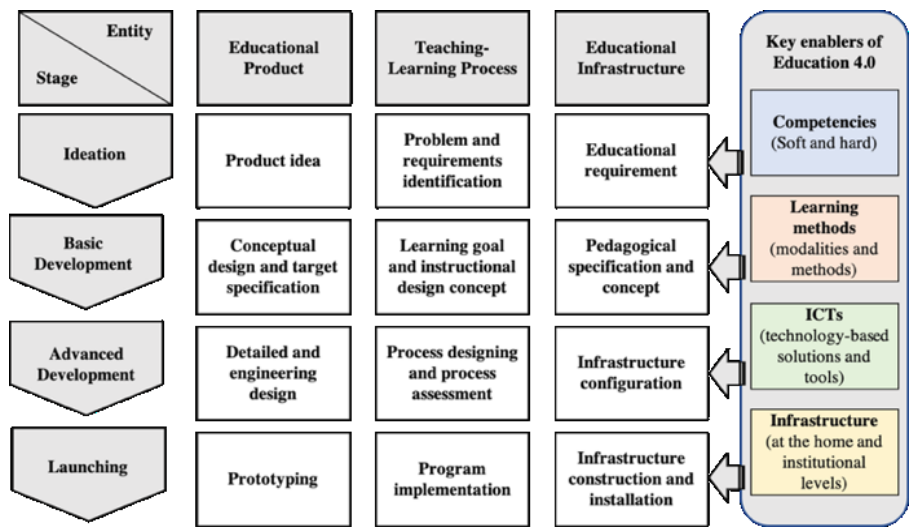

Fig. 1. The Education 4.0 reference framework for designing teaching-learning systems

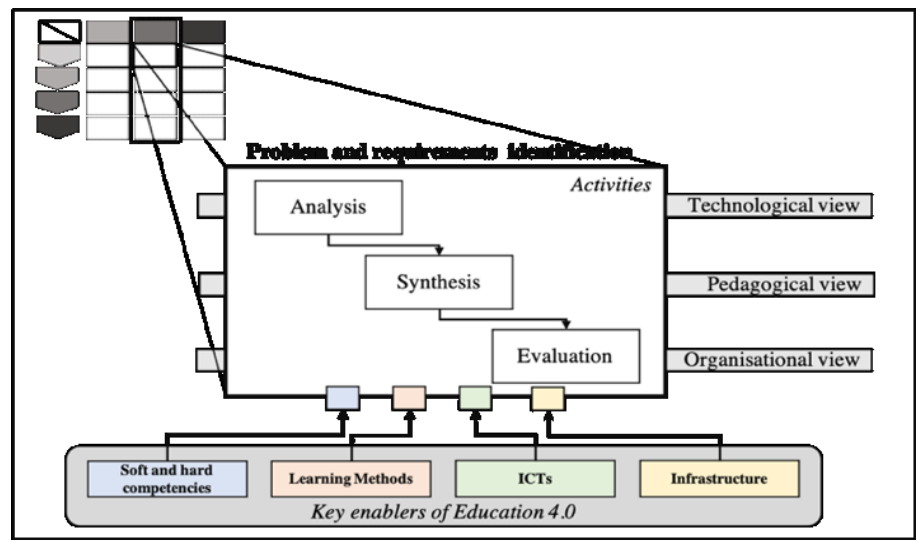

Fig. 2. Performed activities at the problem and requirements identification stage (example) 


\section{Design of Teaching-Learning Programs: Two Case Studies Appling Collaborative Networks and Open Innovation}

\subsection{Case study: The Innovation Challenge Bootcamp as a Driver to Promote Open Innovation}

In China, the government, higher education institutions, and organisations are promoting initiatives to improve the quality of engineering education, the internationalisation of higher education through collaborative/joint programs, and the acceleration of China's progress as a manufacturing powerhouse and leader in innovation, technology and science [18]. In this context, there is a lack of alternative credentials in engineering education that address holistically the topics related to developing technology-based products, creativity and innovation [19]. So, Tecnologico de Monterrey University in Mexico, through its Innovation Hub facility in China, promotes OI activities such as co-design and co-development, entrepreneurship, and technology transfer. Furthermore, it considers the participation of strategic partners from governments, universities, and companies in both countries. The following case study presents a hybrid learning program taught to students from China and Mexico. The main objective of this program is that students from both countries collaborate to propose technology-based solutions to current social problems. Figure 3 presents a summary of the results obtained by using the proposed reference framework for the design of this bootcamp. See Fig. 3.

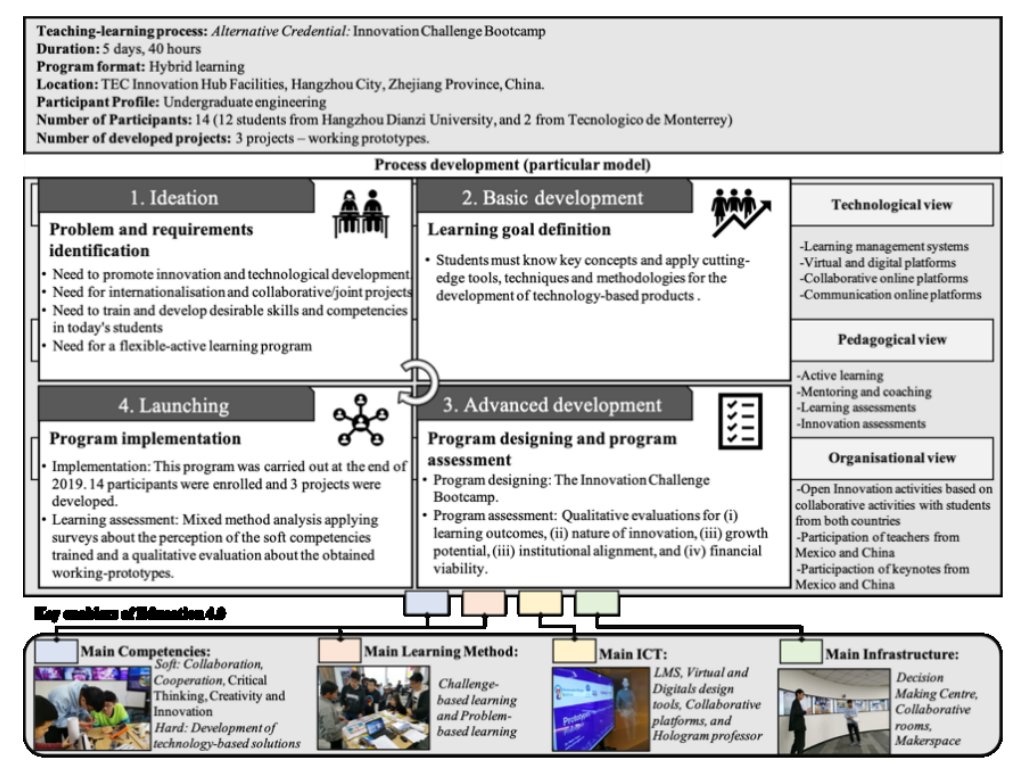

Fig. 3. Summarised results of the development process of the Innovation Challenge Bootcamp applying the teaching-learning process of the Education 4.0 reference framework 


\subsection{Case study: Collaborative Online International Learning}

Processes that create new options benefit societal development. Innovation leads to the generation of new services, products and technologies. Analysing the possibilities in different countries will help us propose options in our regions (Latin America). In this case study, the "Collaborative Online International Learning" (COIL) activity provides a collaborative experience among various academic disciplines and countries. The objective of this COIL activity was to develop critical thinking skills, effective communication, innovation and collaborative work. By the end of this experience, the students should have developed their capacity for effective communication through online interactions with people from different cultures and disciplines. This program works with the proposed reference framework to develop competencies using experiential methods, ICT integration, and open infrastructure environments. See Fig. 4.

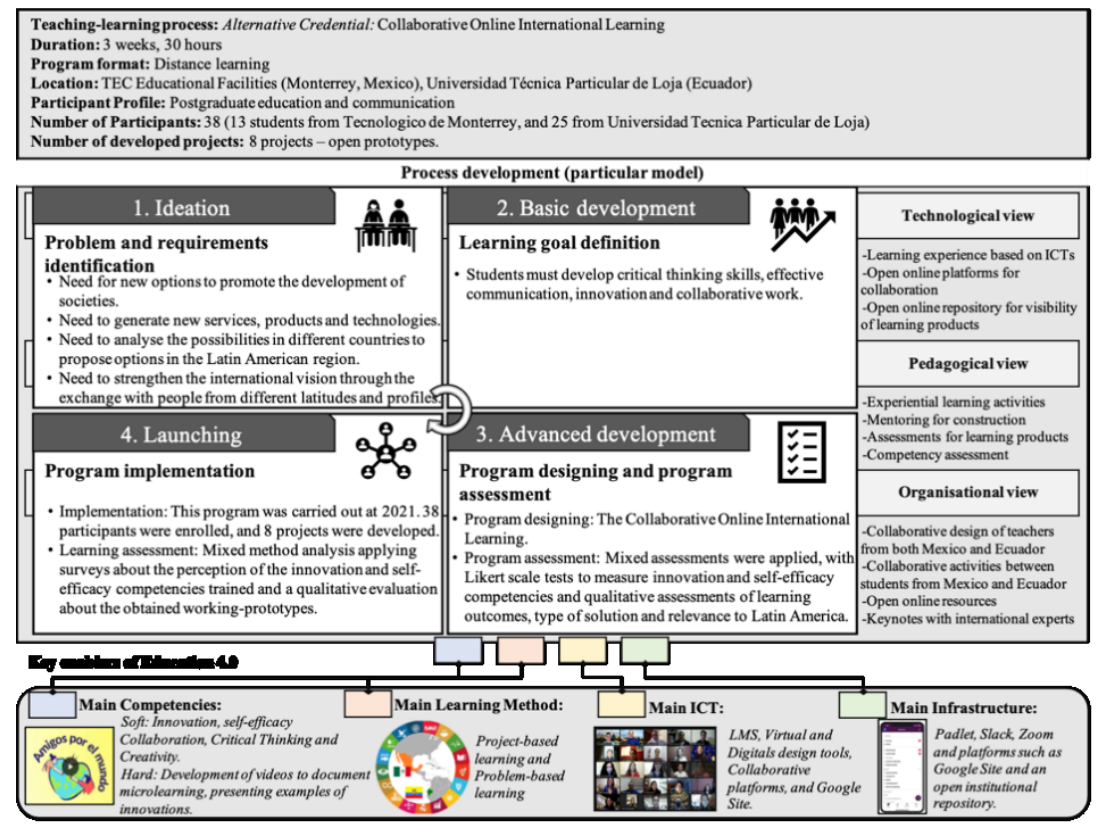

Fig. 4. Summarised results of the development process of the Collaborative Online International Learning applying the teaching-learning process of the Education 4.0 reference framework

\section{Conclusions and Future Work}

In this work, we propose a reference framework for the design of teaching-learning systems in Education 4.0. Then, the design and development of new educational products, processes and infrastructure are supported. Furthermore, this reference framework allows educational innovators to guide them while creating systems that adopt the concept of Education 4.0. We accomplished this by providing the main components shaping Education 4.0 in a toolbox comprised of its four key enablers. 
Finally, an evaluation was carried out to validate the technological, pedagogical and organisational components used within the system produced.

We also presented two case studies to illustrate how the proposed framework is used to design teaching-learning processes in academic programs. The presented case studies show three main results: (i) Using the proposed reference framework, new educational systems with their desired components can be obtained in the period of Education 4.0. Hence, this reference framework can be an engine for educational innovation. (ii) Using the proposed reference framework can be a driver to promote collaboration and cooperative activities because the technologies employed and the active learning activities applied induce the forming of collaborative networks and the implementation of open innovation strategies. (iii) The creation of multidisciplinary teams, the participation of international partners during teaching-learning processes, and the shared use of infrastructure were possible thanks to existing CNs that promote not only research and development activities but also teaching-learning activities.

Future work will focus on three specific lines:

(i) Improving the decision-making process to better define particular models. For example, validate the answers to the following questions (a) what are the key competencies to be promoted and how assess these competencies? (b) what are the learning methods that best match with learning goals? (c) What are the best ICTs and infrastructure to be applied according to particular teaching-learning process?

(ii) Define a complete set of the analyses, syntheses and evaluation activities.

(iii) Provide a set of metrics and indicators during the validation and evaluation process to quantitatively measure the systems produced per the three proposed primary views: technological, pedagogical and organisational.

Acknowledgement. The authors would like to acknowledge the technical support of Writing Lab, Institute for the Future of Education, Tecnologico de Monterrey, Mexico, in the production of this work.

\section{References}

1. Wan, J., Cai, H., Zhou, K.: Industry 4.0: Enabling Technologies. In: 2015 International Conference on Intelligent Computing and Internet of Things (IC1T), Harbin, China, 2015, pp. $135-140(2015)$

2. Camarinha-Matos, L. M., Fornasiero, R., Afsarmanesh, H.: Collaborative Networks as a Core Enabler of Industry 4.0. In: 18th Working Conference on Virtual Enterprises (PRO-VE), Vicenza, Italy. pp. 3-17 (2017)

3. Roman, M., Varga, H., Cvijanovic, V., Reid, A.: Quadruple Helix Models for Sustainable Regional Innovation Engaging and Facilitating Civil Society Participation. In: Economies, vol. $8(2), 48(2020)$

4. Mehmet, E.: An IDEA for design pedagogy: Devising instructional design in higher education 4.0. In: Design and Technology Education, vol. 26, no 1, pp. 118-136 (2021) 
5. Ayub, E., Wei, G. W., Luaran, J. E., Keppell, M. J., Leong, L. C., Mohamad, S. N. A.: A design and development research approach to redesigning an online module for education 4.0. In: IEEE Conference on e-Learning, e-Management \& e-Services, pp. 1-6 (2019)

6. Das, S., Kleinke, D. K., \& Pistrui, D.: Reimagining engineering education: does industry 4.0 need education 4.0?. In: ASEE Virtual Annual Conference Experience (2020)

7. World Economic Forum.: Schools of the Future, Defining New Models of Education for the Fourth Industrial Revolution. Geneva: World Economic Forum (2020)

8. Miranda, J., Navarrete, C., Noguez, J., Molina-Espinosa, J. M., Ramírez-Montoya, M.S., Navarro-Tuch, S.A., Bustamante-Bello, M.R., Rosas-Fernández, J. B., Molina, A.: The Core Components of Education 4.0 in Higher Education: Three Case Studies in Engineering Education. In: Computers and Electrical Engineering, in press (2021)

9. Huggins, R., Prokop, D., \& Thompson, P.: Universities and open innovation: The determinants of network centrality. In: The Journal of Technology Transfer, vol. 45 (3), pp. 718-757 (2020)

10. Jnr, A., B., Petersen, A.: Examining the digitalisation of virtual enterprises amidst the COVID-19 pandemic: a systematic and meta-analysis. In: Enterprise Information Systems, vol. 30, pp. 1-34 (2020)

11. Borissova, D., Dimitrova, Z., \& Dimitrov, V.: How to Support Teams to be Remote and Productive: Group Decision-Making for Distance Collaboration Software Tools. In: Information \& Security, vol. 46 (1), pp. 36-52 (2020)

12. Himmelman, A. T.: On coalitions and the transformation of power relations: Collaborative betterment and collaborative empowerment. In: American Journal of Community Psychology, vol. 29 (2), pp. 277-284 (2001)

13. Camarinha-Matos, L.M., Afsarmanesh, H.: Collaborative Networks: A New Scientific Discipline. In: Journal of Intelligent Manufacturing, vol. 16, No. 4-5, pp. 439-452 (2005)

14. Chesbrough, H.: Open innovation: The new imperative for creating and profiting from technology. Boston, MA: Harvard Business School Press (2003)

15. Molina, A., Sánchez, J. M., Kusiak, A.: (Eds.), Handbook of Life Cycle Engineering: Concepts, Models and Technologies, ISBN 978-0-412-81250-7, Springer-Verlag US (1999)

16. Molina, A., Ponce, P., Miranda, J., Cortés, D.: Enabling Systems for Intelligent Manufacturing in Industry 4.0: Sensing, Smart and Sustainable Systems for the Design of S3 Products, Processes, Manufacturing Systems, and Enterprises. Springer Nature (2021)

17. López-Cruz, C. S., Heredia, Y.: Escala i, Guía de Aplicación. In: Tecnológico de Monterrey, Mexico (2017)

18. Mei, W., Symaco, L.: University-wide entrepreneurship education in China's higher education institutions: issues and challenges. In: Studies in Higher Education, pp. 1-17 (2020)

19. Shen, J., Li, T., Wu, M.: The New Engineering Education in China. In: Procedia Computer Science, vol. 172, pp. 886-895 (2020) 